\title{
OPTIMIZATION OF TEACHING METHODS IN SPORTS CLASSES WITH STUDENTS WITH VISUAL IMPAIRMENTS
}

\author{
Mariana Albert ${ }^{1}$, Evald Albert ${ }^{2}$ \\ ${ }^{1}$ Medical University- Sofia, Medical College "J. Filaretova" \\ ${ }^{2}$ National Sports Academy "Vassil Levski"
}

\begin{abstract}
The motivation for conducting the present research is the creation of kinesitherapeutic algorithms adapted to visually impaired student so that they can achieve greater autonomy and activity in motor skills during sports classes.

The aim of the study is to develop a kinesitherapeutic program to improve the physical fitness of students with visual impairments during their sports classes.

Tasks: To explore the peculiarities of the students' adaptation to regular physical workload; To analyze the students' social behavior and attitude within and outside the group; To optimize the methods of teaching sport.

The research was done among 105 people (male and female) with major Visionimpaired Masseurs. The Kinesitherapeutic Program included five successive stages: 1. Improving coordination 2. Training proper breathing. 3. Investigating and practicing Chi gon exercise. 4. Learning and applying yoga exercises. 5. Filling in a questionnaire.

The survey shows that $82.86 \%$ of students believe the kinesitherapeutic program improves their autonomy and locomotion activity, increases their motor skills and physical fitness.

The kinesitherapeutic program is applicable to pupils as well as students with visual disturbances with different majors.

For the first time, sports classes combine Chi gong and yoga exercises with static-strength workouts and balance exercises to increase physical activity as well as to prevent and treat clinical conditions associated with visual disturbances.
\end{abstract}

Keywords: students with visual disturbances, sports classes 


\section{INTRODUCTION}

Blindness ranks among the gravest sensory lesions as a condition, accompanied by functional losses of physical, mental and social aspect. Absence of vision or its extreme reduction causes very serious limitations in all possible spheres of human activities (Houwen et al., 2009). Numerous studies have shown that depending on the character of the process of vision loss, the age of acquiring the defect and the extent of vision limitations there is an additional psychic trauma, leading to serious psychic lack of adaptation and aggravated mental health (Gal, Dyk, 2009), (Radulov, TsvetkovaArsova, 2011). The difficulties and inconveniences that a visually impaired child encounters while playing games, attaining various motor habits or studying bring about complicated experiences and negative reactions. They are expressed by uncertainty, inertness, self-isolation with tendencies to autistic disturbances, inadequate behavior and sometimes aggressiveness (Deniskina, 2012).Visual problems influence attention due to disturbances in the mental pictures, and due to children's insu fficient knowledge (Gurkova, 2006). Attention is lowered as a result of emotional-volitional problems. Absent-mindedness and chaotic state are observed. Tiredness occurs faster as a result of the long lasting irritation caused by the acoustic analyzer (Wiskochil et al., 2007).

One of the characteristic features of the sightless' physical development is the insufficient growth of the muscular system. It is considerably weaker compared to that of the sighted because of the lower motor activity (Lyudmilova, Dimitrova, 2010).
One of the most important factors for the blind's development and realization is overcoming isolation from their very close social circles (Vidolov, 2002). Most people with damaged vision are constantly looked after by their families. They are used to being surrounded by their relatives, parents and friends. That is why an abrupt change will be a difficult obstacle for them. Upon enrolling at a university, they have to become autonomous in their activities and adapt to the new way of life. They have to cope with the whole education process themselves and to socialize with the other students at the university.

Many students with visual impairments tend to have a reduced willingness to work, nervous tension, and increased fatigue. All these can cause emotional disturbances, feelings of discomfort, breaches of balance between the stimulus and suppressive processes in the cerebral cortex. There are some individuals with impressive will and others who do not display it at all, who have impulsive behavior, suggestibility, obstinacy and negativism (Litvak, 2006). Students' main task is to learn the teaching material which is also their lecturers' responsibility because they should prepare qualified specialists, capable of adequate realization in the health system.

In our work with people with visual problems we apply all pedagogical methods, admitting some differences in their apprehension.

We modify them, according to students' physical abilities, knowledge and skills, their previous visual and motor experience, spatial orientation and ability to use residual vision. The application of phonic, tactile, olfactory, and other 
reference points are of priority importance.

The emotional aspect of classes depends on the variety of drills, the teacher's tone, intonation and commands. The pitch of the voice changes (loud, quiet, gentle, strict). It depends on the mental state of the learners, their condition, and the perception of the material.

Non-traditional sports equipment is used: sound balls (goal balls); balls with handles; flavored apparatuses (odor of vanilla); steppers; cones for the development of the vestibular apparatus.

For the development of tactile sensitivity devices for finger manipulations and mastering fine motor skills are used (massage balls and small rings of the type "hedgehog", manual expanders, elastic bands etc.).

For the development of spatial orientation exercises for coordination and synchronization with a partner are applied (Tsarova, Andonov, Alexandrova, 2012).

The distant method is particularly appropriate when working with visually impaired young people. Students' motions during performance of practical drills are directed with commands ("push down harder", "a step forward", "come nearer").

The knowledge perception method is built on the basis of information perception during training through the sensory organs (audition, sense of touch, olfaction, and vision). The method aims at practitioners' becoming aware of the muscle-motor feeling, appearing in the muscles or joints when performing a certain movement or technique, so that they could apply it in practice.
The method of visualization is very important when training the blind and the purblind (Tolmachev, 2004). Demonstrativeness is a training method with the most specific peculiarities in the process of getting to know objects and actions. During their acquaintance with certain objects (sports or massage equipment), students first touch them and then have to define their shape, type of surface, color, features. Later a question is asked about the entire perception of the object or action. For a better comprehension of the teaching material, it is advisable that all apparatuses be in very bright colors red, yellow, green, orange.

It is obligatory to present the activity with verbal description in order to activate learners' mental activity. (Albert, 2015).

Method of stimulated motor activity - The absence of clear visual images reduces emotional life of people with visual disturbances (Anfilatova, 2005). These students need to be encouraged to get rid of their inferiority complex, of their uncertainty and fear of space. Under their trainer's guidance they play highly emotional games for mastering their motor skills.

Visual impairments are always connected with disturbances in the locomotive activity. Years of experience have shown that the improvement of such students' possibilities of doing locomotive activity leads to improvement of their autonomy and is a prerequisite for more adequate acquisition of professional knowledge and skills.

\section{PURPOSE AND OBJECTIVES OF THE STUDY}

The aim of the study is to develop a 
kinesitherapeutic program for optimization of sports classes and improvement of the physical fitness of students with visual impairments.

\section{Tasks:}

1. To explore the peculiarities of the students' adaptation to regular physical workload.

2. To analyze the students' social behavior and attitude within and outside the group.

3. To optimize the methods of teaching sport.

Our research studies the implementation of new means in sports classes, such as the Chinese healing gymnastics Chi Gong, asanas and elements from yoga, as well as special respiratory exercises. The designed program can be used when training students in unequal condition at different universities.

On the basis of the literary survey and the analysis of the data from a number of studies on education and professional realization of people with visual problems, we presume that an appropriate kinesitherapeutic program will stimulate the adaptation of visually impaired students with major Massage to a regular physical workload and they will achieve greater autonomy and improve their motor skills.

\section{MATERIALS AND METHODS Participants}

The present study was held during the period 2002-2014 with students of „Y. Filaretova” Medical College, Sofia among 105 visually impaired students (male and female), divided into two groups:
I group - experimental group (EG) 75 students;

II group - control group (CG) - 30 students.

During the classes with both groups in the gymnasium we very often worked with students without visual disturbances at the same time.

The subjects (randomly chosen) were first- and third-year students with major Visually Impaired Masseur.

The experimental group consisted of students who did sport regularly in the form of kinesitherapeutic schemes, combined with yoga and Chi Gong elements, modified and complemented by us. All students had submitted medical documents and permits by their doctors in order to participate in the experiment.

The EG consisted of 35 women (46.6\%) and 40 men (53.4\%). In the CG women and men were equal in number - fifteen, which represented $50 \%$ of the group. In both groups women's average age was 20 years. Men's average age was 22, and they represented 53.4\% of EG and $50 \%$ of CG. The carried out studies showed that the respondents in both groups were evenly and not deliberately distributed.

The students with major Visually Impaired Masseur had to be with a certain degree of disablement (Table 1). In EG, $27.9 \%$ of the men and women were categorized as having first degree of disablement and $71.9 \%$ as having second degree of disablement. In CG, they were respectively $26.6 \%$ and $73.3 \%$. This fact required an individual approach, differentiated work and taking into consideration the various degrees of vision disturbance with each of them. 
Table 1. Characteristics of the subjects by their degree of disablement

\begin{tabular}{ccccccc}
\hline \multirow{2}{*}{$\begin{array}{c}\text { Degree of disablement } \\
\text { (TELC) }\end{array}$} & \multicolumn{3}{c}{ EG } & \multicolumn{3}{c}{ CG } \\
\cline { 2 - 6 } & Women & Men & Number & Women & Men & Number \\
\hline \multirow{2}{*}{ First degree of disablement } & 13 & 8 & 21 & 5 & 3 & 8 \\
Second degree of disablement & $(17.3 \%)$ & $(10.6 \%)$ & $28 . \%$ & $(16.6 \%)$ & $(10 \%)$ & $26.6 \%$ \\
Total & $(29.3 \%)$ & $(42.6 \%)$ & $72 \%$ & $(33.3 \%)$ & $(40 \%)$ & $73.3 \%$ \\
& 35 & 40 & 75 & 15 & 15 & 30 \\
\hline
\end{tabular}

${ }^{\star} T E L C=$ Medical expert committee for work capacity

The distribution of first and second degree of disablement was even in the groups

\section{Organization of the work}

At the very beginning of the experiment, the researched individuals from $E G$ and $C G$ were treated under equal conditions. That way, their social affiliation was studied and its effect on their efficient education

The classes were held twice a week the regular two classes of the sports program.

The duration of each class was from 45 to 60 minutes.

The period of study was 3 years for each student during the entire course of training at college.

Optimization of teaching methods with students with visual impairments

If students with visual disturbances are not given the chance to express themselves and do not join the society of other students, they will become social invalids. This is a serious challenge to lecturers' professional skills.

Practice work with visually impaired people has proven that they are good lis- teners, but they do not always understand what they are told or explained. In connection with that, we paid greater attention to perceptions by explanation and image. Both in regular and sports classes a story is the most often used type of lecture. In our practice we specified the following requirements to the lecturers:

First, they have to be good psychologists to predispose the students with visual disturbances to the environment, in which they are taught; to have good diction without speech disorders in order to be able to speak correctly and present the educative material in a way suitable for the students. They should conform to the possibilities of the students as regards the syllabus.

The questions during training must be asked in a suitable pitch of the voice that does not suppress students. When working with blind students, one should leave some time for reflection due to the fact that they need to think about and "depict" the question.

During our work with the students we abided by the following methodical rules:

- Teachers have to ask accurately and 
exactly all types of questions to avoid incorrect interpretation and receiving wrong answers;

- Teachers do not ask general questions and reasoning, which would stress on the students' vision problems, during specific learning process, such as: "Do you know what a ball is?", "Do you see how sunny the weather is outside?", "When you look at your right hand, you will see..." Questions of such type emphasize on their anomaly (visual disturbance) and would lead to students' withdrawal and to a breach in the education environment;

- The gymnasium should be quiet and students are seated in front of the teacher at a close distance;

- The light in the gymnasium is in compliance with their visual comfort;

- Eye gestures should be avoided as they will not be noticed;

- Students should be motivated to take active part in the lesson;

- Teachers should know and apply law frames when working with visually impaired people.

Another important peculiarity with the blind is that we work with them in small groups, and in each group there are not only entirely blind students but also ones with different degrees of visual disturbances.

Teachers facilitate socializing while students acquire new skills and knowledge.

The methods of kinesitherapy consist of five stages performed in strict sequence. Keeping this order is a guarantee for developing and increasing practitioners' physical qualities. The drills are explained in details because the students have various extents of visual damage, zero vision included, and they cannot observe a demonstration. Each drill is explained and played by the teacher, then a student does it with some help and if he/ she manages to do it by himself/herself, does it unassisted.

We gave names to the drills to call forth associations in the blinds' minds and to help their comprehension. In this way only by giving the name, the drill is set and done.

The applied kinesitherapeutic methods with EG differ from the ones used during sports classes with CG in the following indices:

- the density of the class is bigger;

- the speed of the execution of the kinesitherapeutic exercises is average;

- specific means of kinesiotherapy (adapted yoga complex, Chi Gong exercises, specific poses etc.) are included.

Workload: The specific classes were of average to submaximal workload. They were chosen according to the extent of students' physical development, functional capacity, and peculiarities of their psychomotor activity.

After the kinesitherapeutic complexes were implemented and learnt, we held a physical fitness test (Albert, 2015)

First stage: a special complex for developing and improving coordination and spatial orientation. The exercises for eye focus increase the ability of the crystalline lens to focus vision at different distances; accommodation is improved. The exercises increase and develop the power of the oculomotor muscles. Skills for focusing the attention on a certain object are acquired. (Albert, 2014).

This stage lasted for three months, 
but some of the exercises were also used in the next stages.

Second stage: training proper breathing. There is a special yoga complex for improving breathing and increasing functional capacities of the spinal column, tendons, joint ligaments and viscera. Before practicing yoga exercises, the practitioner should empty his/her urinary bladder and intestines. The exercises should not be done quickly, but precisely and correctly to have good healing effect. To be remembered more easily, the exercises were given characteristic names, which facilitated trainers' work with the blind.

This stage lasted for five months.

Third stage: development of quality flexibility. On this level, students played a complex of exercises from the Chinese gymnastics Chi Gong, adapted by us for visually impaired people. Specific exercises for balancing the energy in the body and aiding the visual analyzer were executed. They were also present in the successive stages.

This stage lasted for five months.

Chi Gong exercises for eyes, included in the kinesitherapeutic program, increase vital forces of the organism.Before doing the exercises, in a brief lecture course, the students were presented with the essence, principles and philosophy of the healing method.

The healing Chi Gong complexes included a combination of movements, breathing exercises and meditation techniques (work of thoughts, consciousness), point massages and self-massages. When working with the blind, the trainer aids their arm movements during the first performance and reminds for the directions during the implementation of each exer- cise. During training the teacher corrects the posture and helps the students with spatial orientation, only if he/she has perception or zero vision. If necessary, he/ she performs the movement passively, so that the practitioner could feel it.

When applying the Chi Gong complexes, we took into consideration the following instructions:

- Special attention is paid to relaxation of all parts of the body, achieving maximum relaxation of the muscles of the neck, shoulders and waist, reaching a state of mental peace, calming down consciousness.

- Movements are done slowly without extra efforts.

- Each movement passes easily into the next one.

- Breathing is calm and even, slowed down.

- Students are informed that before classes they should empty their urinary bladders and intestines.

- Exercises are not executed in less than 30 minutes time after eating (the practitioner should not be very hungry or thirsty before the start of the training).

\section{Contraindications}

People with mental diseases must not practice Chi Gong. The other contraindications coincide with the ones in kinesiotherapy.

Fourth stage: increasing muscle strength. We developed a complex of poses in static isometric-isotonic contraction, necessary for building up muscle power without considerable loading of the visual analyzer (Table 6). This stage lasted for two months.

Fifth stage: drills, combined with 
meditation. This stage is the most important for building up visual memory (Albert, 2014). It lasted for six months.

The entire program lasted for 21 months.

We developed example schemes and complexes to be included in the kinesitherapeutic methods (Albert, 2015).

\section{METHODOLOGY OF THE STUDIES}

The emphasis was on the following components: observation and a questionnaire for evaluation of the extent of students' adaptation to the physical workload; the influence of the complex program on students' way of learning and perception.

\section{Questionnaire}

Each participant had to fill in the questionnaire at the end of the threeyear period of training, after receiving their final grades. This was done to avoid subjectivism and suggestion on the answers. The questions covered all areas (communication, concentration, orientation, psycho-emotional status, physical fitness) (App. 1).

\section{RESULTS}

The data from the questionnaire were analyzed with the $\mathrm{x} 2$ method. It is a statistical method for verification of hypotheses (a nonparametric class of method). Cramer's coefficient was used to measure the degree of connection among the variables (within limits from 0 to 1 ). When this coefficient gets values between 0.00 and 0.30 the connection is weak, between 0.30 and 0.70 - average, and from 0.7 to 1 - strong. The explanation of this coefficient is possible only if its level of signifi- cance is lower than the admissible error $\alpha$ $=0.05$.

As an answer to the first question $52.38 \%$ of all students stated that they wished to do sport every day. In EG $46.67 \%$ showed their wish to train every day, and $48 \%$ of the interviewees - three times a week. The results for the CG were the following: $16.67 \%$ would train every day, $63.33 \%$ - three times a week and $20.00 \%$ once a week. The coefficient of variation $\mathrm{V}(0.354)$ for $\mathrm{EG}$ is less than $\mathrm{V}$ (0.378) for CG, which means equal distribution of the replies in EG (Tables 2 and 3). The results showed that the whole group, with the exception of $5.33 \%$, wished to do sport regularly. These data prove that young people have accepted and approved the KT program as means for improving their functional condition. It helped them to get used to doing regular physical activities and to get satisfaction of the achieved results. In CG 32.87\% did not show interest in sports training. This percentage included students with zero vision who have difficulty in doing sport, and students who are overweight. It is harder for them to overcome the mental barrier to participate more actively in sports events.

The answers to the second question (How does noise influence you during classes?) showed $-81.33 \%$ from EG and $63.33 \%$ from the CG, or $76.19 \%$ of all - that noise had disturbed them considerably. $23.81 \%$ of all participants - respectively $18.67 \%$ from EG and $36.67 \%$ from CG noise were slightly influenced by the noise. The coefficient of variation $\mathrm{V}(0.154)$ for EG is less than V (0.240) for the CG (Tables 2 and 3). These data showed that the answers are homogenous 
and noise is a basic barrier for the normal doing of common activities by the visually impaired, because they receive most of their necessary information through their visual analyzers (Fig. 1a and 1b).

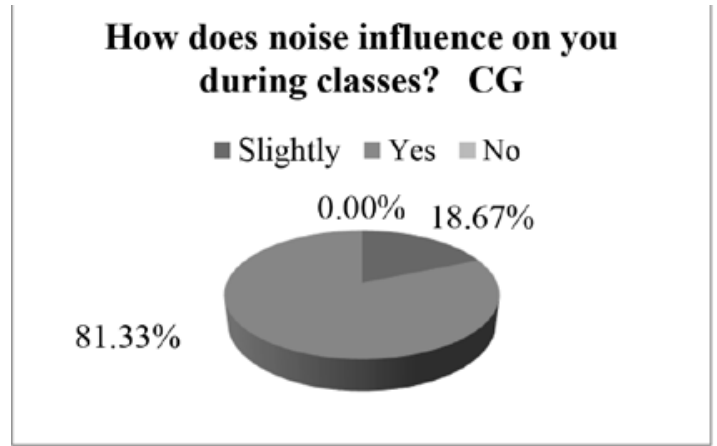

Figure $1^{\mathrm{a}}$. Answers in $C G$.

To the third question $84.76 \%$ of all students replied with "Yes", $13.33 \%$ with "satisfactory" and only $1.90 \%$ did not like sports classes. For the EG the „Yes” results were $90.67 \%$, and for the CG - 70\% and with "satisfactory" $9.33 \%$ and for the CG $-23.33 \%$. Only $6.67 \%$ from the CG replied that they did not like sports classes. The coefficient of variation $\mathrm{V}$ for the EG (0.086) is considerably lower than that for the CG (0.378). That shows the homogenous attitude of the experimental group. We believe that the implementation of numerous drills and different techniques contributed to the positive answers. The successful combination of Chi Gong and yoga exercises as well as the smooth transition among them, eye exercises and self-massage on certain acupuncture points are the reason for the high results of the EG

In the answer to the question „Does sport contribute to improving your health?" the EG was unanimous about the favorable role of sport on healing processes. There the coefficient of variation is zero and with the $\mathrm{CG}-\mathrm{V}$ is (0.064).
These students require silence during lectures because lots of them use Dictaphones to record them. None of the students marked that noise did not influence him/her.

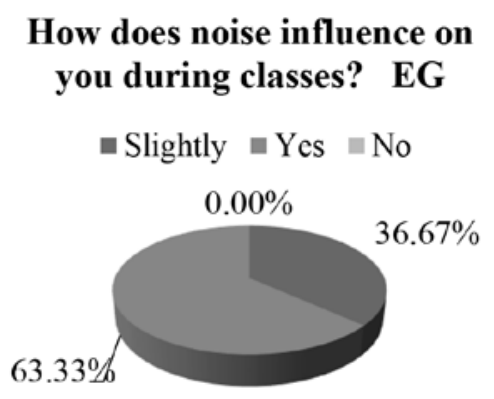

Figure $\mathbf{1}^{\mathbf{b}}$. Answers in $E G$

$93.33 \%$ of the CG answered with "Yes" and $6.67 \%$ - slightly. The data showed considerable homogeneity in both groups. Only one student stated that sport had had slight effect on his health $(1.90 \%)$. Students in unequal condition willingly participate in sports classes, take active part, depending on the extent of their disabilities. Much more young people care about their health, pay attention to their physical qualities and look for appropriate programs for regular training.

The opinion of $89.52 \%$ of the students, concerning the question ,Does sport increase your efficiency?" was that regular sports trainings increased their working capacity. $6.58 \%$ of them considered that the role of the drills was insignificant. $76.67 \%$ of the CG and $95 \%$ of the EG reported positive results. $16.67 \%$ for the $C G$ and $5 \%$ for the EG thought that sport had slightly influenced their efficiency; and $6.67 \%$ had negative attitude (Fig. 2a and 2b). When we compared the coefficients of variation $\mathrm{V}(0.51)$ of $\mathrm{EG}$ and $\mathrm{V}(0.335)$ of $\mathrm{CG}$ we saw there was a considerable statistical difference. 


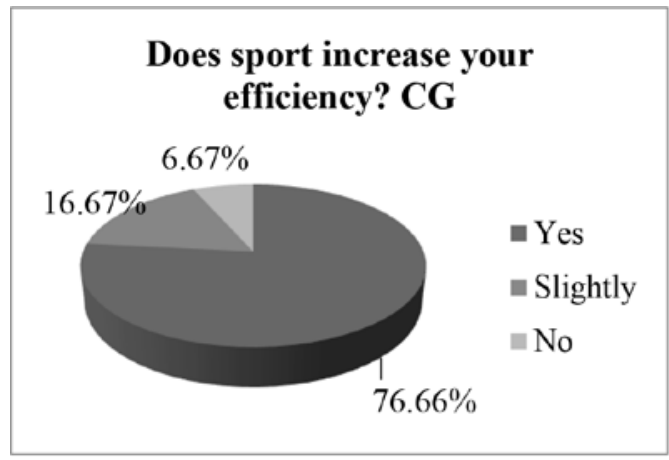

Figure 2a . Answers of $C G$

Sports events create favorable conditions for new acquaintances and social contacts - this was the answer of $87.62 \%$ of the students to the question „Do sports activities improve your contacts with other students?". Of them only $9.52 \%$ thought they had insignificant role and $2.86 \%$ - the events did not contribute to their social contacts. In the EG $90.67 \%$ stated that sport helped their socialization, respectively $80 \%$ in the CG. $8 \%$ in the $\mathrm{EG}$ and $13.33 \%$ in the $\mathrm{CG}$ believed its role was insignificant; and only $1.33 \%$ of the CG answered with „No”. The coefficient of variation is 0.124 , and of the CG- $\mathrm{V}$ is 0.340 . The data displayed bigger homogeneity in the EG, nevertheless various answers were observed. We noticed that it was more difficult for women to get into contact during sports training.

The answer to the question „Do bright colors of apparatuses and aids help you?" showed the substantial role of bright colors for their perception by the visually impaired people - $98.10 \%$ of all students. The answer ,slightly" $(1.90 \%)$ was given by people with zero vision. The utilization of brightly colored apparatuses supports sports activity of the visually disturbed, for example when they play table-tennis with a yel-

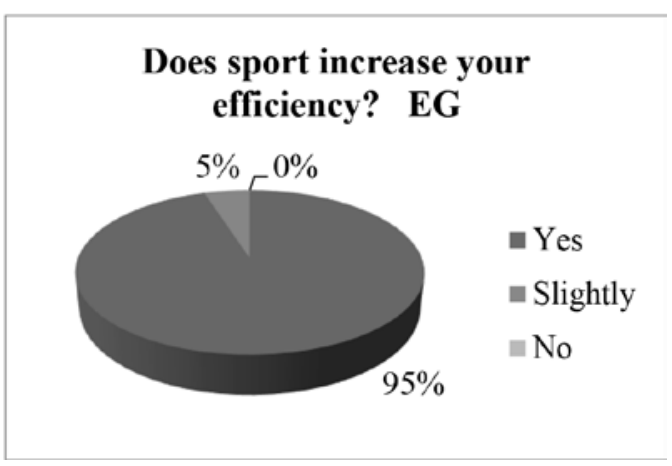

Figure $2^{\mathbf{b}}$. Answers of $E G$

low ball, they play much better and for a longer time.

„Do you cope with terminology?" This question provided information about the level of the acquisition of teaching material. Most of the students (89.52\%) thought that they had mastered medical terminology, partly - 8.57, and 1.90\% stated that they had not coped with it. The data by groups are: in the EG 95\% - ,Yes" answers and respectively $76.67 \%$ in the CG; insignificantly" - 5\% in the EG and $16.67 \%$ in the CG; and "No" answers $6.67 \%$ in the CG. The coefficient of variation is 0.51 , but in the $\mathrm{CG}(\mathrm{V}=0.355)$. The results showed greater homogeneity in the EG (Table 2).

The question of visually impaired concentration is of particular importance. $78 \%$ of them admitted the role of the yoga exercises for their better results. The rest $19.05 \%$ believed that their concentration had been slightly influenced by them, and $2.86 \%$ gave negative answers. By groups the results are: with positive answers $88 \%$ in the $\mathrm{EG}$ and $53.33 \%$ in CG; slight influence $10.67 \%$ in the EG and $40 \%$ in the CG. Only $6.67 \%$ in the CG and $1.33 \%$ in the EG denied the positive effect of these exercises. The coefficient of variation is 
$(\mathrm{V}=0.144)$ in the $\mathrm{EG}$ and $(\mathrm{V}=0.395)$ in the CG. This shows that students from the EG shared one and the same opinion

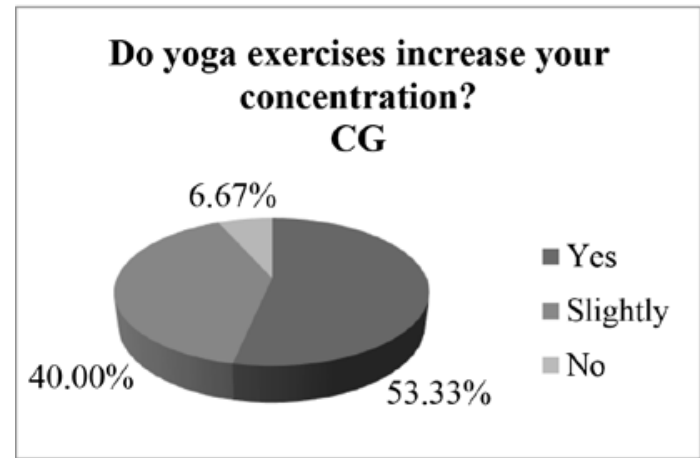

Figure $3^{\mathrm{a}}$. Answers in the $C G$

The responds to question 10 (,How does eye gymnastics influence you?") do not include the control group (CG), because the students from this group did not perform that complex during the experiment. $90.67 \%$ of the EG reported these drills had contributed to the improvement of their condition and only $9.33 \%$ indicated a slight betterment. The positive assessment of the students is the result of precisely selected eye exercises combined with self-massage at certain acupuncture points affecting the visual analyzer. With students with zero vision, included in the EG, the results were insignificant because they considered only the influence on their emotional condition.

For visually impaired people orientation in the surroundings is vital. Of all the students $86.67 \%$ replied that the complex of exercises had improved their orientation, $11.43 \%$ - it had been slightly improved and only $1.90 \%$ indicated a negative result. By groups the data are: with "Yes" answers 95\% in the EG and $66.7 \%$ in the $\mathrm{CG} ; 5 \%$ marked slight effect in the EG and $26.67 \%$ in the CG; $6.67 \%$ - without any change in the $C G$ about the effect of yoga on concentration and there is a statistically significant difference (Fig. 3a and 3b).

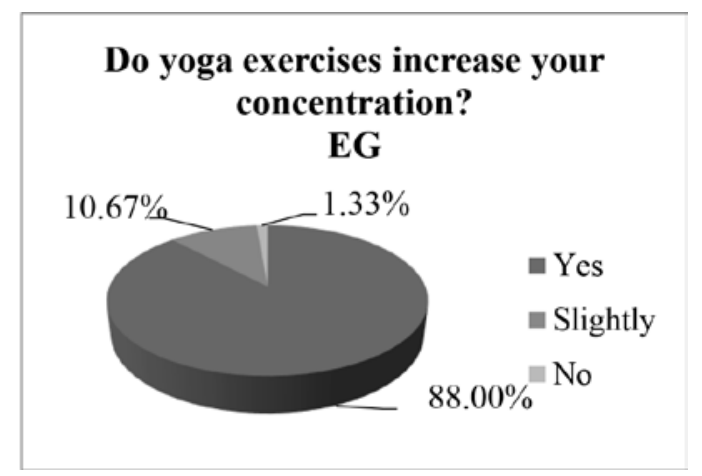

Figure $3^{\mathbf{b}}$. Answers in the $E G$

(Figure $4 \mathrm{a}$ and $4 \mathrm{~b}$ ). The coefficient of variation is $(\mathrm{V}=0.51)$ in the $\mathrm{EG}$ and $(\mathrm{V}=0.386)$ in the $\mathrm{CG}$, and that shows a statistically considerable difference.

The questionnaire has proven that $66.67 \%$ of all students wish to do the complex of exercises, $3.81 \%$ would do it sometimes, but $29.52 \%$ do not think it is necessary to do it. In the EG $67 \%$ replied with "Yes", 29\% would play sometimes and $4 \%$ do not want to do it.

To the question "What is the effect of sport on your psycho-emotional status", $95.24 \%$ of all students replied positively, with $2.86 \%$ the result was satisfactory and only with $1.90 \%$ it was negative. The opinion of the whole EG was that sport had considerably affected their psychoemotional status and that is why the coefficient of variation is $(\mathrm{V}=0)$. In the $\mathrm{CG}$ $83 \%$ supported the opinion of the EG, $33.33 \%$ thought that sport had affected their psyche insignificantly, and $6.67 \%$ denied its influence (the coefficient of variation $\mathrm{V}$ is 0.323 ).

KT program has improved physical fitness to $82.86 \%$, satisfactory results have been achieved $15.24 \%$, and with $1.90 \%$ there have not been any changes. 


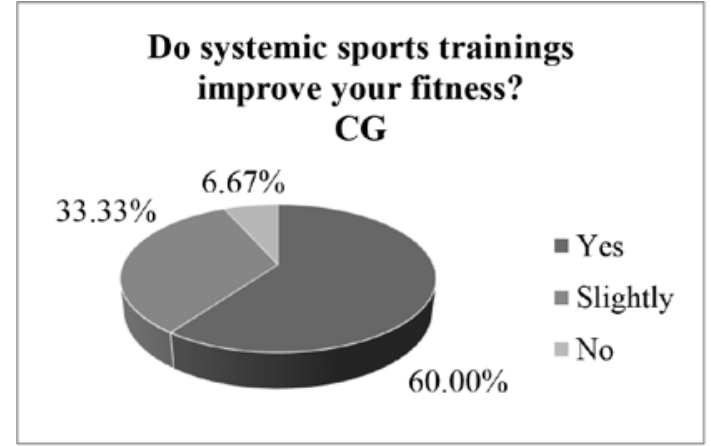

Figure $4^{\mathrm{a}}$. Answers in the $C G$

In EG $92 \%$ and $60 \%$ in the CG admitted betterment in their physical fitness as a result of the regular sports classes. Only $8 \%$ in the EG and $10 \%$ in the $\mathrm{CG}$ reported slight result, and $6.67 \%$ in the $\mathrm{CG}$ had not had improvement in

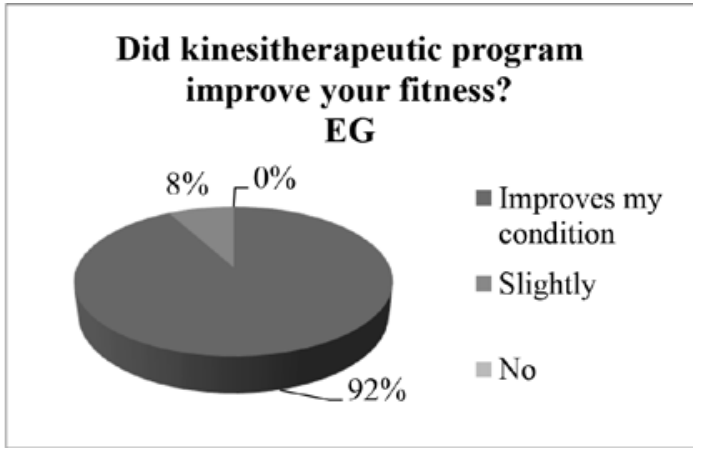

Figure $4^{\mathrm{b}}$. Answers in the $E G$

their condition (Fig. 4a and 4b). The coefficient of variation is $(\mathrm{V}=0.75)$ in the EG and $(\mathrm{V}=0.395)$ in the CG. The results have displayed statistically considerable differences between both groups (Tables 2 and 3 ).

Table 2. Replies of the EG

\begin{tabular}{|c|c|c|c|c|c|c|c|c|c|c|c|}
\hline $\begin{array}{l}\text { Descriptive } \\
\text { Statistics }^{\mathbf{a}}\end{array}$ & $\mathbf{N}$ & Range & Min & $\operatorname{Max}$ & Mean & $\begin{array}{l}\text { Std } \\
\text { Dev }\end{array}$ & Var & \multicolumn{2}{|c|}{ Skewness } & \multicolumn{2}{|c|}{ Kurtosis } \\
\hline Group $=$ Experimental & Stat & Stat & Stat & Stat & Stat & Stat & Stat & Stat & $\begin{array}{c}\text { Std } \\
\text { Error }\end{array}$ & Stat & $\begin{array}{c}\text { Std } \\
\text { Error }\end{array}$ \\
\hline $\begin{array}{l}\text { 1. How many times a week would } \\
\text { you do sport? }\end{array}$ & 75 & 2 & 1 & 3 & 1.59 & .595 & ,354 & ,44 & ,27 &,- 65 &, 54 \\
\hline $\begin{array}{l}\text { 2. How does noise influence you } \\
\text { during classes? }\end{array}$ & 75 & 1 & 1 & 2 & 1,19 & ,392 &, 154 & 1,64 &, 27 & ,71 &, 54 \\
\hline 3. Do you like sports classes? & 75 & 1 & 1 & 2 & 1,09 & ,293 & ,086 & 2,85 & ,27 & 6,30 &, 54 \\
\hline $\begin{array}{l}\text { 4. Does sport contribute to im- } \\
\text { provement of your health? }\end{array}$ & 75 & 0 & 1 & 1 & 1,00 &, 000 &, 000 & . & . & . &, 54 \\
\hline $\begin{array}{l}\text { 5. Does sport increase your ef- } \\
\text { ficiency? }\end{array}$ & 75 & 1 & 1 & 2 & 1,05 & ,226 & ,051 & 4,05 & ,27 & 14,8 &, 54 \\
\hline $\begin{array}{l}\text { 6. Do sports activities improve } \\
\text { your contacts with other students? }\end{array}$ & 75 & 2 & 1 & 3 & 1,11 &, 352 &, 124 & 3,50 & ,27 & 12,8 &, 54 \\
\hline $\begin{array}{l}\text { 7. Do bright colors of apparatuses } \\
\text { and aids help you? }\end{array}$ & 75 & 0 & 1 & 1 & 1,00 &, 000 & ,000 & . & . & . & \\
\hline 8. Do you cope with terminology? & 75 & 1 & 1 & 2 & 1,05 &, 226 &, 051 & 4,05 &, 27 & 14,8 &, 54 \\
\hline $\begin{array}{l}\text { 9. Do yoga exercises increase your } \\
\text { concentration? }\end{array}$ & 75 & 2 & 1 & 3 & 1,13 &, 380 &, 144 & 2,93 &, 27 & 8,63 &, 54 \\
\hline $\begin{array}{l}\text { 10. How does eye gymnastics } \\
\text { influence you? }\end{array}$ & 75 & 1 & 1 & 2 & 1,09 & ,293 & ,086 & 2,85 &, 27 & 6,30 &, 54 \\
\hline $\begin{array}{l}\text { 11. Did the applied exercises } \\
\text { improve your orientation? }\end{array}$ & 75 & 1 & 1 & 2 & 1,05 & ,226 & ,051 & 4,05 &, 27 & 14,8 &, 54 \\
\hline $\begin{array}{l}\text { 12. Would you keep on doing the } \\
\text { complex of exercises? }\end{array}$ & 75 & 2 & 1 & 3 & 1,08 & ,319 & ,102 & 4,35 &, 27 & 20,2 & ,548 \\
\hline $\begin{array}{l}\text { 13. What is the effect of sport on } \\
\text { your psycho-emotional status? }\end{array}$ & 75 & 0 & 1 & 1 & 1,00 &, 000 & ,000 & . & . & . & . \\
\hline $\begin{array}{l}\text { 14. Did kinesitherapeutic pro- } \\
\text { gram improve your fitness? }\end{array}$ & 75 & 1 & 1 & 2 & 1,08 & ,273 & ,075 & 3,16 &, 27 & 8,20 & ,548 \\
\hline
\end{tabular}


Table 3. Replies of the $C G$

\begin{tabular}{|c|c|c|c|c|c|c|c|c|c|c|c|}
\hline \multirow{2}{*}{$\begin{array}{c}\begin{array}{c}\text { Descriptive } \\
\text { Statistics }^{\mathrm{a}}\end{array} \\
\text { Group/ Control }\end{array}$} & \multirow{2}{*}{$\begin{array}{c}\mathbf{N} \\
\text { Stat }\end{array}$} & \multirow{2}{*}{$\begin{array}{c}\text { Range } \\
\text { Stat }\end{array}$} & \multirow{2}{*}{$\begin{array}{l}\text { Min } \\
\text { Stat }\end{array}$} & \multirow{2}{*}{$\begin{array}{c}\text { Max } \\
\text { Stat }\end{array}$} & \multirow{2}{*}{$\begin{array}{c}\text { Mean } \\
\text { Stat }\end{array}$} & \multirow{2}{*}{$\begin{array}{l}\begin{array}{c}\text { Std } \\
\text { Dev }\end{array} \\
\text { Stat }\end{array}$} & \multirow{2}{*}{$\begin{array}{l}\text { Var } \\
\text { Stat }\end{array}$} & \multicolumn{2}{|c|}{ Skewness } & \multicolumn{2}{|c|}{ Kurtosis } \\
\hline & & & & & & & & Stat & $\begin{array}{l}\text { Std } \\
\text { Error }\end{array}$ & Stat & $\begin{array}{l}\text { Std } \\
\text { Error }\end{array}$ \\
\hline $\begin{array}{l}\text { 1. How many times a week } \\
\text { would you do sport? }\end{array}$ & 30 & 2 & 1 & 3 & 2,03 &, 61 &, 37 &,- 016 & ,42 &,- 092 & ,83 \\
\hline $\begin{array}{l}\text { 2. How does noise influence } \\
\text { you during classes? }\end{array}$ & 30 & 1 & 1 & 2 & 1,37 &, 49 &, 24 &, 583 & ,42 & $-1,78$ &, 83 \\
\hline 3. Do you like sports classes? & 30 & 2 & 1 & 3 & 1,37 &, 61 &, 37 & 1,50 & ,42 & 1,33 & ,83 \\
\hline $\begin{array}{l}\text { 4. Does sport contribute to } \\
\text { improvement of your health? }\end{array}$ & 30 & 1 & 1 & 2 & 1,07 &, 25 &, 06 & 3,66 & ,42 & 12,2 & ,83 \\
\hline $\begin{array}{l}\text { 5. Does sport increase your } \\
\text { efficiency? }\end{array}$ & 30 & 2 & 1 & 3 & 1,30 &, 59 & ,35 & 1,90 & ,42 & 2,74 &, 83 \\
\hline $\begin{array}{l}\text { 6. Do sports activities } \\
\text { improve your contacts with } \\
\text { other students? }\end{array}$ & 30 & 2 & 1 & 3 & 1,27 &, 58 &, 34 & 2,14 & ,42 & 3,74 & ,83 \\
\hline $\begin{array}{l}\text { 7. Do bright colors of appa- } \\
\text { ratuses and aids help you? }\end{array}$ & 30 & 1 & 1 & 2 & 1,07 &, 25 & ,06 & 3,66 & ,42 & 12,2 & ,83 \\
\hline $\begin{array}{l}\text { 8.Do you cope with termi- } \\
\text { nology? }\end{array}$ & 30 & 2 & 1 & 3 & 1,30 & ,59 & ,35 & 1,90 & ,42 & 2,74 & ,83 \\
\hline $\begin{array}{l}\text { 9.Do yoga exercises increase } \\
\text { your concentration? }\end{array}$ & 30 & 2 & 1 & 3 & 1,53 & ,62 & ,39 & ,758 & ,42 &,- 321 & ,83 \\
\hline $\begin{array}{l}\text { 10.How does eye gymnastics } \\
\text { influence you? }\end{array}$ & 30 & 0 & 3 & 3 & 3,00 &, 00 &, 00 & . & . & . & . \\
\hline $\begin{array}{l}\text { 11.Did the applied exercises } \\
\text { improve your orientation? }\end{array}$ & 30 & 2 & 1 & 3 & 1,40 & ,62 & ,38 & 1,33 & ,42 &, 831 & ,83 \\
\hline $\begin{array}{l}\text { 12. Would you keep on doing } \\
\text { the complex of exercises? }\end{array}$ & 30 & 0 & 3 & 3 & 3,00 &, 00 &, 00 & . & . & . & . \\
\hline $\begin{array}{l}\text { 13. What is the effect of sport } \\
\text { on your psycho-emotional } \\
\text { status? }\end{array}$ & 30 & 2 & 1 & 3 & 1,23 & ,568 & ,323 & 2,428 & ,427 & 5,036 & ,83 \\
\hline $\begin{array}{l}\text { 14.Did kinesitherapeutic } \\
\text { program improve your fit- } \\
\text { ness? }\end{array}$ & 30 & 2 & 1 & 3 & 1,47 & 629 & ,395 & 1,025 & ,427 & 113 & ,83 \\
\hline
\end{tabular}


An integral system for improvement of physical fitness of visually impaired students has been developed, including special eye gymnastics combined with balance and coordination training. The chosen way of arranging exercises in a fixed order, dosage and consistency is a significant contribution in the theory and practice of kinesitherapy:

- The findings concerning the role of physical fitness on the psycho-emotional state of the students, the effect of the noise and colors on the visually impaired - all are in accordance with the results of other researchers.

- The optimized teaching methods are also applicable to students at schools and with visually disturbed students with

\section{REFERENCES}

Алберт, М., Маринов, Е., 2014, Изследване влиянието на комплекс „гимнастика за очите" върху зрителните функции на студенти с нарушено зрение, Научно списание ,Доклади, изследвания, публикации” с. 17-25. (Albert, М., Marinov, E., 2014, Izsledvane vliyanieto na kompleks "gimnastika za ochite" varhu zritelnite funkzii na studenti s narusheno zrenie, Nautchno spisanie "Dokladi, izsledvania, publikazii”, s. 17-25.)

Алберт, М., 2015, Изследване влиянието на кинезитерапевтичен комплекс върху слуховата памет на студенти със зрителни нарушения. Сп. Здраве и наука, с.4-9. (Albert, M., 2015, Izsledvane vliyanieto na kineziterapevtitshen kompleks varhu sluhovata pamet na studenti sas zritelni narushenia. Sp. Zdrave i nauka, c.4-9.)

Алберт, М., 2015, Кинезитерапевтична програма за подобряване на физическата дееспособност при сту- different majors.

\section{CONCLUSION}

The implementation of the kinesitherapeutic program, designed by us, during the 3-year period of training of visually impaired massage students, has stimulated them to take part in regular physical workloads suitable for their health condition; has had an expressed positive psycho-emotional effect; has assisted their social adaptation and has increased their autonomy and activity in locomotion and their motor skills.

It can be recommended as part of the complex rehabilitation for the improvement of the quality of life of visually impaired people.

денти със зрителни нарушения. Дис (Albert, M., 2015, Kineziterapevtitshna programa za podobriyavane na fizitcheskata deesposobnost pri studenti sas zritelni narushenia. Dis.)

Анфилатова, О., 2005, Методика непрерывного адаптивного физического воспитания детей старшего дошкольного возраста с нарушением зрения, Физическая культура, 2, с. 50. (Anfilatova, O., 2005 Metodika neprerivnovo adaptivnavo fizitsheskavo vozpitania deteiiaдаптивного физического воспитания детей starshevo doshkolnovo vozrasta $\mathrm{s}$ narusheniem zrenia, Fizitsheskaj kultura, 2, s. 50)

Видолов, Д., 2002, Представата за себе си - основен фактор в обучението по мобилност и ориентиране при зрително затруднени, Личност, мотивация, спорт. София, с. 46. (Vidolov, D., 2002, Predstavata za sebe si - osnoven faktor $\mathrm{v}$ obutshenieto po mobilnost i orientirane pri zritelno zatrudneni, Litchnost, morivazia, sport. Sofia, s. 46.) 
Гуркова, Е., 2006, Особенности адартационных реакций организма на физические нагрузки оздравительного характера у детей 8-10 лет с нарушением зрения. Теория и практика физической культуры. Москва, 8, с.45 (Gurkova, E., 2006, Osobenosti adaptationix reactii organizma nafizitsheskite nagruzkiozdravitelnovo haraktera $\mathrm{u}$ deca 8-10 let s narusheno zrenie, Theorya $i$ Practica, Fizitsheskaj kultura. Moscow, 8, p.45.)

Денискина, В., 2012 Особые образовательные потребности, обусловленные нарушениями зрения и их вторичными последствиями, Дефектология, 5, с.5664. (Deniskina, V., 2012 Educational Needs, Substantial Disorders and Secondary Impacts. Defectology, 5, pp. 56-64.)

Литвак, А., 2006, Психология слепых и слабовидящих. Учеб. пособие для студентов высш. Пед. Учеб. Заведений, СПб.: КАРО, с. 1-324 (Litvak, A., 2006 Psychologya slépix I slabovidiajshix. Learning, Pedd. Learning. Zavedenii, SPb. KARO, pp. 1-324.)

Людмилова, И., Димитрова, Д., 2010, Влияние на спортната дейност върху силовата издръжливост на деца и младежи с увредено зрение, Спорт, стрес, адаптация. ч. 1, Пети межоународен научен конгрес Олимпийски спорт и спорт за всички., София с. 398. (Lyudmilova, I., Dimitrova, D., 2010, Vliyanie na sportnata aktivnost varhu silovata izdrajlivost na deca s uvredeno zrenie. Sports, stress, adaptaciya. 1, Peti Internationalen Nautchen Congress Olimpiiski Sport i Sport za Vsichki, Sofia p. 398.)
Радулов, В., Цветкова-Арсова, М. 2011, Психология на зрително затруднените. София, СИК Феномен, с. 38-107. (Radulov, V., Tsvetkova-Arsova, M., 2011 Psychologya na zritelno zatrudnenite, Sofia, SIC Phenomen, pp. 38-107.)

Толмачев, Р., 2004, Адаптивная физическа культура и реабилитация слепых и слабовидящих. Советский спорт, Москва, 2004, с. 108. (Tolmachev, R., 2004 Adaptive, Physical Culture and Rehabilitation, Slim and Weakening. Sovetskii sport, Moscow, p. 108.)

Църова, Р., Андонов, К., Александрова В., 2012 Специализирана методика за обучение на деца с нарушено зрение, Спорт и наука, София, извънр. бр. №6, c. 12-20. (Tsarova, R., Andonov, K., Alexandrova V., 2012 Specializirana methodika za obutцhenie na deca $\mathrm{s}$ narusheno zrenie, Sport i nauka, Sofia, izv. broi 6, pp. 12-20.)

Gal E., M. Dyk., 2009, Stereotyped Movements among Children who are Visually Impaired, Journal of Visual Impairment and Blindness, vol. 103,11, p. 754-765.

Houwen, S., Hartman, E., \& Cisscher, C., 2009, Physical activity and motor skills in children with and without visual impairments, Medicine \& Science in Sports \& Exercise, 40(1), p. 103-109.

Wiskochil, B., Lieberman, L.J., Houston-Wilson, C., \& Petersen, S., 2007, The effects of trained peer tutors on academic learning time-physical education on four children who are visually impaired or blind, Journal of Visual Impairment and Blindness, 101, p. 339-350.

\section{Correspondence:}

Mariana Albert Medical University - Sofia, Medical College "J. Filaretova", Bulgaria E-mail: andial@mail.bg 